\title{
PENGELOLAAN, PEMANFAATAN DAN KEABSAHAN HAK KEPEMILIKAN ATAS TANAH ADAT BERDASARKAN PERATURAN ADAT DIWILAYAH KEDAMANGAN KECAMATAN TIMPAH KABUPATEN KAPUAS.
}

Oleh:

DEDE SURYANTO

\begin{abstract}
Abstrak
Tanah adalah unsur ruang yang strategis dan pemanfaatannya terkait dengan penataan ruang wilayah. Penataan ruang wilayah, mengandung komitmen untuk menerapkan penataan secara konsekuen dan konsisten dalam kerangka kebijakan pertanahan yang berlandaskan Undang-Undang Nomor : 5 Tahun 1960, tentang Peraturan Dasar Pokok-Pokok Agraria. Dalam kehidupan manusia bahwa tanah tidak akan terlepas dari segala tindak tanduk manusia itu sendiri, sebab tanah merupakan tempat bagi manusia untuk menjalani dan melanjutkan kehidupannya. Maka untuk itu diperlukanlah kaidah-kaidah yang mengatur hubungan antara manusia dengan tanah. Di dalam Hukum Adat, tanah ini merupakan masalah yang sangat penting. Hubungan antara manusia dengan tanah sangat erat.

Kehidupan masyarakat Indonesia yang masih bercorak Agraris membuat masayarakat giat dalam meningkatkan hasil buminya melalui cara bercocok tanam sebagai penyambung hidup, salah satunya yang terkait dengan pengelolaan dan pemanfaatran Tanah Adat pada masing-masing daerah yang masih berpegang teguh terhadap aturan-aturan adat setempat. Seperti yang terjadi pada daerah aliran sungai Kapuas, Kalimantan Tengah, yang berlokasi di wilayah Kedamangan Kapuas Tengah yaitu khususnya terletak di Kecamatan Timpah. Masyarakat Kecamatan Timpah hingga saat ini masih menjunjung tinggi peraturan adat-istiadatnya. Berkaitan dari hal tersebut maka sangat menarik bagi penulis untuk meneliti terkait dengan Pengelolaan dan pemanfaatan Tanah Adat serta bagaimana Keabsahan kepemilikan Hak atas Tanah Adat menjadi Hak milik Perorangan atau Hak milik suatu Kelompok masyarakat di wilayah Kedamangan Kecamatan Timpah Kabupaten Kapuas.
\end{abstract}

Kata Kunci : Pengelolaan, Pemanfaatan dan Keabsahan Hak atas Tanah Adat.

\section{PENDAHULUAN}

Bangsa Indonesia merupakan bangsa yang majemuk yang kaya akan berbagai macam adat istiadat, kebudayaannya yang beragam pada tiap-tiap daerah yang terbentang dari sabang sampai meraoke, baik itu dari segi adat istiadatnya, suku bangsa maupun kepercayaan/agama yang dianut. Dari 
semua itu memiliki karakteristik dan keunikan masing-masing dengan berbagai keanekaragamannya. Namun walaupun demikian adanya, tidaklah mempengaruhi dan menghalangi makna persatuan dan kesatuan bangsa Indonesia sebagaimana tertuang dalam semboyan "Bhineka Tunggal Ika" yang artinya walaupun berbeda-beda, tetapi tetap satu juga satu Bangsa Indonesia.

Tanah adalah unsur ruang yang strategis dan pemanfaatannya terkait dengan penataan ruang wilayah. Penataan ruang wilayah, mengandung komitmen untuk menerapkan penataan secara konsekuen dan konsisten dalam kerangka kebijakan pertanahan yang berlandaskan Undang-Undang Nomor : 5 Tahun 1960, tentang Peraturan Dasar PokokPokok Agraria. Maka untuk itulah diperlukan kaedah-kaedah yang mengatur hubungan antara manusia dengan tanah. Di dalam Hukum Adat, tanah ini merupakan masalah yang sangat penting. Hubungan antara manusia dengan tanah sangat erat, seperti yang telah dijelaskan diatas, bahwa tanah sebagai tempat manusia untuk menjalani dan melanjutkan kehidupannya. Dengan demikian maka jelaslah bahwa tanah sebagai sumber utama bagi kehidupan manusia sebagai tumpuan masa depan, dan kesejahteraan manusia itu sendiri, berdasarkan jalan pemikiran tersebut, dipertegas pula dalam Undang-Undang Dasar 1945 pasal 33 ayat 3 yang berbunyi; Bumi air dan kekayaan alam yang terkandung di dalamnya dikuasai oleh Negara dan dipergunakan untuk sebesar-besar kemakmuran rakyat.

Kemudian PERGUB Kalimantan Tengah Nomor: 13 Tahun 2009, tentang Tanah Adat dan Hak-Hak Adat diatas Tanah di Provinsi Kalimantan Tengah, yang dalam asas tujuan dan fungsi pada Pasal 2. Disana dijelaskan dan dipertegaskan pula pada ayat 1 yang berbunyi; "Pengaturan tanah adat dan hak-hak adat diatas tanah dilaksanakan berdasarkan asas pengayoman dan kepastian hukum".

Kemudian dilanjutkan pada ayat 2 yang berbunyi;

Pengaturan tanah adat dan hak-hak adat diatas tanah diselenggarakan dengan tujuan untuk melindungi, mengakui dan 
menghargai hak masyarakat adat untuk melestarikan adat yang hidup dimasyarakat guna menunjang keberhasilan pembangunan dan kelancaran jalannya pemerintahan, serta memperjelas kepemilikan, penguasaan dan pemanfaatan tanah adat dan hak-hak adat diatas tanah.

Dari ketentuan dasar inilah kemudian dapat diketahui bahwa pada ayat 3 yang menjelaskan mengenai fungsi pengaturan tanah adat dan hakhak adat atas tanah adalah :

untuk menunjang keberlangsungan hidup (livelihoold), dan meningkatkan kesejahteraan anggota masyarakat adat, baik yang bersifat sosial maupun ekonomis, serta juga sebagai petunjuk atau jati diri tentang kepemilikan dan penguasaan menurut ketentuan hukum adat yang berlaku, yang apabila dikehendaki oleh pemegang haknya dapat didaftarkan sebagai hak atas tanah yang sesuai menurut ketentuan Undang-Undang Pokok Agraria (UUPA).

Dalam hal ini kita bisa lihat di wilayah kedamangan Kecamatan Timpah Kabupaten Kapuas, bahwa pengelolaan dan penataan lingkungan hidup, yang bagian utamanya adalah tanah juga mengandalkan hukum yang berlaku secara Nasional disamping pengaturan hukum adat setempat untuk menjadi dasar pengaturannya. Namun walaupun demikian adanya tetap saja sebagian masyarakat setempat tidak menaati dan menyadari bahwa tanah adat dan hak-hak adat atas tanah itu sudah diatur sesuai dengan aturan hukum adat yang berlaku.

Jadi dari uraian di atas, maka penulis dapat menyimpulkan bahwa jelas sekali ada suatu permasalahan yang penulis harus luruskan, dimana permasalahan tersebut berkaitan dengan judul penelitian yang penulis angkat yaitu tentang; Pengelolaan dan Pemanfaatan Tanah Adat serta Keabsahan hak kepemilikan atas Tanah Adat berdasarkan peraturan Adat diwilayah Kedamangan kecamatan Timpah Kabupaten Kapuas.

\section{PEMBAHASAN}

\section{Beberapa pengertian Tanah Adat menurut para Mantir Adat dan Tokoh tetua Adat setempat}

Sebelum mengupas lebih dalam terkait pengelolaan dan pemanfaatan tanah Adat menurut beberapa penyelenggara Adat di wilayah Kedamangan 
kecamatan Timpah. Maka terlebih dulu akan dibahas arti dan tujuan tanah adat berdasarkan hasil wawancara dilapangan bersama para Mantir Adat dan tokoh-tokoh tetua Adat setempat.

Wawancara, tanggal 5 Juli 2010, dengan Bpk. Punding W. Daron, beliau menerangkan kembali tentang pengertian tanah adat bahwa yang dimaksud dengan tanah adat itu adalah tanah yang berada dikawasan atau wilayah kecamatan yang terbagi atas desa-desa yang keberadaannya dikuasai berdasarkan hukum adat, adapun jenis tanah adat yang dikuasai dimaksud, yaitu baik itu yang berupa hutan belukar semata, maupun yang masyarakat setempat miliki secara peorangan dan secara bersama/berkelompok yang keberadaannya diakui oleh Lembaga Kedamangan setempat.

Selanjutnya menurut Indar Rawan (wawancara, 13 Juli 2010), Tanah Adat adalah tanah yang dimiliki atau dikuasai oleh hukum adat dan dilindungi lembaga kedamangan, fersi kedua jenis tanah adat yang dilindungi dan dikuasai oleh hukum adat di Kecamatan Timpah yaitu : tanah PukungPehewan, tanah Rutas (bekas tempat orang meninggal sehingga di rutas kan tempat itu), Kayuan tempat Tajahan (kawasan ini ada hubungannya dengan binatang tempat masyarakat melaksanakan ritual Manajah Antang), lokasi Tanggiran, tanah Keramat (Janah Bagana, Danau Bagana, dan Talaga Bagana), Sepan, dan Payan. Ada pun tanah atau kawasan yang dilindungi keberadaannya oleh lembaga adat yaitu berupa hutan belukar yang berada di wilayah Kecamatan Timpah yang dilarang sama sekali merusak termasuk mencemari hutan tersebut. Apabila ada masyarakat yang ingin menggarap tanah tersebut maka dia harus meminta ijin dari Damang Kepala Adat dan Kepala Desa setempat untuk membuka lahan tersebut sebagai tempat berladang/bersawah. Selain minta ijin dari Kepala Adat dan Kepala Desa yang bersangkutan juga wajib berkeyakinan untuk melaksanakan upacara ritual sebagai salah satu tradisi turun temurun yaitu mampakanan ganan taluh petak (memberikan sesajen kepada roh-roh penunggu alam) agar pada saat menggarap tanah tersebut tidak mendapat 
marabahaya/malapetaka dan tanah yang ingin digarap tadi bisa menjadi tempat berkebun atau bercocok tanam.

Selanjutnya Sutar Rawan (wawancara, 8 Juli 2010) menyatakan tanah adat adalah tanah yang dikuasai berdasarkan hukum adat yang keberadaannya diakui oleh Damang sebagai Kepala Adat. Adapun jenis tanah adat itu seperti ; tanah PukungPehewan, tanah Rutas, Kayuan tempat Tajahan, lokasi Tanggiran, tanah Keramat (Janah Bagana, Danau Bagana, dan Talaga Bagana), Sepan, dan Payan. Kemudian tanah adat yang dimiliki secara bersama-sama adalah tanah warisan leluhur turun temurun yang dikelola dan dimanfaatkan bersama-sama oleh para ahli waris sebagai sebuah komunitas. Dalam hal ini dapat disejajarkan maknanya dengan Hak Ulayat. Sedangkan tanah adat milik perorangan adalah tanah milik pribadi yang diperoleh dari membuka hutan atau berladang, hasil jual beli, hibah atau warisan secara adat, dapat berupa kebun atau tanah yang ada tanam tumbuhnya maupun tanah kosong belaka.

\section{Pengelolaan dan Pemanfaatan Tanah Adat di wilayah Kedamangan Kecamatan Timpah dan dasar Keabsahan Kepemilikan Hak Atas Tanah Menurut Hukum Adat Setempat}

Hukum Adat dapat dirumuskan sebagai konsepsi yang komunelistik religius, memungkinkan penguasaan tanah secara individual dengan hakhak atas tanah yang bersifat pribadi, sekaligus mengandung unsur kebersamaan. Sifat komunelistik menunjukkan adanya hak bersama para anggota masyarakat hukum adat atas tanah adat yang dalam kepustakaan hukum disebut hak ulayat.

Tanah ulayat merupakan tanah kepunyaan bersama, yang diyakini sebagai peninggalan/karunia dari para leluhur atau nenek moyang kepada kelompok yang merupakan masyarakat hukum adat, dimana sebagai unsur pendukung utama bagi kehidupan dan penghidupan kelompok masyarakat adat tarsebut sepanjang masa. Disinilah tampak sifat religius atau unsur keagamaan dalam hubungan hukum adat antar warga masyarakat hukum adat dan tanah ulayatnya itu. (Boedi Harsono, 2007:183).

Dalam Pergub. Kalimantan Tengah No. 13 Tahun 2009 tentang Tanah Adat dan Hak-Hak Adat diatas Tanah di Propinsi Kalimantan Tengah pasal 8 ayat (1) menyatakan bahwa Surat Keterangan Tanah (SKT) 
Adat dan hak-hak adat diatas Tanah yang menunjukan hak kepemilikan atau penguasaan atas tanah adat dan hak-hak adat diatas tanah dibuat :

- Atas nama para ahli waris untuk tanah adat milik bersama;

- Atas nama perorangan untuk tanah adat milik perorangan;

- Atas nama para ahli waris atau atas nama perorangan untuk hakhak adat diatas tanah.

Kemudian dilanjukan katerangan ayat (2) yang menyatakan Surat Keterangan Tanah (SKT) adat dan hak-hak adat diatas tanah sebagaimana yang dimaksud pada ayat (1) dapat dijadikan persyaratan utama untuk diproses sesuai ketentuan yang berlaku dalam rangka sertifikasi. Kemudian selanjutnya pada ayat (3) menyatakan Surat Keterangan Tanah (SKT) adat dan hak-hak adat diatas tanah sebagaimana yang dimaksud dapat dijadikan syarat melakukan perjanjian pola kemitraan dengan pihak lain dihadapan pejabat yang berwenang.

Dari uraian pasal 8 ayat (1), (2), dan (3) diatas, jadi dapat disimpulkan dasar keabsahan kepemilikan hak atas tanah adat itu adalah harus memenuhi syarat pasal 8 Selain dapat diwarisi ahli warisnya hak milik juga dapat dialihkan dalam artian dipindahkan kepada pihak lain, misalnya dengan cara jual beli, tukar menukar atau dengan hibah wasiat.

Dasar keabsahan kepemilikan hak atas tanah juga harus didasarkan dasar terjadinya kepemilikan tanah tersebut. Misalnya dalam kaitannya membuka hutan belukar, dimana tanah ditetapkan dengan beberapa ketentuan yaitu berupa;

(1) Bila seseorang atau kelompok masyarakat ingin membuka hutan/tanah untuk dijadikan tempat berladang, bersawah, berkebun maka wajib didahulukan membuat sampaking sementara dan sampaking tetap.

- Sampaking sementara adalah hanya untuk mencari mimpi terhadap pembukaan hutan/tanah yang ingin digarap dengan jangka waktu selama 3 (tiga) hari.

- Sampaking tetap adalah menyatakan hutan/tanah tersebut akan dikerjakan dengan membuka rintisan berkeliling.

(2) Wajib diperiksa oleh pemerintah desa dan mendapat ijin dari Kepala Desa.

(3) Sampaking dibuat dari kayu hidup yang didirikan ditempat yang tampak; 
(4) Bila hutan/tanah yang dibuka untuk tempat berladang/berkebun dan pengerjaannya secara terus-menerus selama 5 (lima) tahun maka tanah tersebut menjadi hak miliknya. (Damang, Punding W Daron, wawancara, 5 Juli 2010 )

Menurut Sutar Rawan (Wawancara, 8 Juli 2010) dasar kepemilikan tanah atau kawasan yang dimiliki oleh lembaga adat itu sendiri diantaranya seperti tanah rutas, tanah pahewan, tanah keramat, tanah-tanah terlarang lainnya itu dimiliki oleh lembaga adat. Apakah dia lembaga Adat Desa atau lembaga adat kedamangan kecamatan, fersi yang kedua tanah adat yang dimiliki secara perorangan, namun tanah tersebut jelas riwayatnya dimiliki sejak paling tidak orang tua atau ibu bapak mereka, dan lebih atas lagi dari nenek kakek mereka, kalau riwayatnya berutun terus boleh dikatakan dari moyang mereka, itu untuk tanah-tanah hak adat yang dimiliki turun temurun untuk pribadi atau silsilah tertentu.

Dasar kepemilikan tanah menurut tokoh adat, Model L Tiwel (Wawancara, 13 Juli 2010) adalah kepemilikannya yang secara turun temurun, maksudnya tidak terbatas jangka waktu penguasaannya dan jika pemiliknya meninggal dunia maka akan dilanjutkan oleh ahli warisnya. Selain dapat diwarisi ahli warisnya, hak milik atas tanah juga dapat dialihkan dalam arti dipindahkan kepada pihak lain yaitu dengan cara transaksi melalui jual beli, tukar menukar, dan hibah wasiat.

Selanjutnya menurut Yansyah G. M (Wawancara, 17 Juli 2010) tokoh adat dasar kepemilikan tanah itu yaitu dengan melalui proses pengolahan ijin Kepala Kampung/Desa diketahui Damang Kepala Adat yang kemudian dikokohkan oleh Camat untuk dijadikan hak milik, baik secara perorangan atau kelompok masyarakat.

\section{Pengaturan atau Undang-Undang yang mengatur Hak dan Kewajiban Masyarakat Adat dalam Pengelolaan dan Pemanfaatan Tanah Adat}

Peraturan yang mengatur hak dan kewajiban masyarakat adat Dayak Ngaju dalam pengelolaan dan pemanfaatan tanah adat yaitu terdapat dalam Pergub. Kalimantan Tengah Nomor 13 Tahun 2009 tentang Tanah Adat dan Hak-Hak Adat di atas Tanah di Propinsi Kalimantan Tengah. Diantaranya yaitu yang terkait pada pasal 1 ayat 12 yang berbunyi; Tanah 
Adat adalah tanah beserta isinya yang berada diwilayah Kedamangan dan atau di wilayah desa/kelurahan yang dikuasai berdasarkan hukum adat, baik berupa; hutan maupun bukan hutan dengan luas dan batas-batas yang jelas, baik milik perorangan atau maupun milik bersama yang keberadaannya diakui oleh Damang Kepala Adat. Selanjutnya mengenai hak-hak adat di atas tanah juga dijelaskan pada ayat 15 yang berbunyi; hak-hak adat di atas tanah merupakan hak bersama maupun hak perorangan untuk mengelola, memungut, dan memanfaatkan sumber daya alam dan hasil-hasilnya, di dalam maupun di atas tanah yang berada di dalam hutan di luar tanah adat.

Kemudian Buku tentang Kewajiban Masyarakat Dalam Memelihara, Melestarikan, Mengembangkan, Dan Ingin Memiliki Hak Adat Berupa : Tanah, Hutan, Untuk Dijadikan Hutan Lindung, Tempat Berladang/Berkebun, Persawahan Serta Tempat Berusaha Dan Berlindung Dalam Mempertahankan Hidup Menurut Adat Dayak Ngaju, Diwilayah Kedamangan Timpah, Kecamatan Timpah, Kabupaten Kapuas Kapuas, Propinsi Kalimantan Tengah. (Punding W. Daron, Damang Kepala Adat Kecamatan Timpah, 2003).

\section{KESIMPULAN}

Berdasarkan dari hasil penelitian ini, maka penulis menarik kesimpulan; masing-masing fungsionaris kedamangan desa/kelurahan dan kecamatan wajib untuk melakukan pengawasan terhadap penggunaan dan pemeliharaan tanah adat dan hak-hak adat diatas tanah dengan didukung olah Majelis Adat Dayak Nasional, Dewan Adat Dayak Propinsi, Dewan Adat Dayak Kabupaten/kota, Dewan Adat Dayak Kecamatan, Dewan Adat Dayak Desa/kelurahan dan seluruh masyarakat Adat Dayak setempat. Hukum Adat Dayak adalah suatu aturan yang patut dipatuhi berupa ketaatan dalam perilaku atau berbuat sesuatu, baik tata krama, tata susila, dan saling menghormati sesama suku atau dengan masyarakat umum, terhadap lingkungan demi menciptakan kehidupan yang beradab (belom bahadat). 
Suatu kawasan hak adat yang dilindungi, dilestarikan dan dimanfaatkan dimana didalamnya terkandung; hutan, tanah, sungai, danau, suaka alam, cagar budaya, pantai, rawa gambut, dan lain-lainnya, yang dikuasa secara turun temurun dan berfungsi sebagai bagian dalam kehidupan masyarakat disekitarnya. Didalam hak adat dimaksud terkandung didalamnya berupa baik kepemilikan dan penguasaan peorangan atau kelompok masyarakat seperti; tanaman tangkawang, garu, jalan pantung, tanggiran, bahu talajan, bahu rimba, petak rutas, anak sungai, danau, beje/ruak/luto/saka, rimba, pahewan, kabun, sepan, andel, rintis/sampaking/parit/pakau, tajahan, tempat pemakaman, kaleka, dan lain-lain. Jadi, kesemuaan itu tadi merupakan wilayah yang dikuasai secara bersamasama oleh masyarakat untuk dimanfaatkan sebagai bagian dalam kehidupan.

Aturan yang mengatur tentang Penguasan Tanah Adat oleh masyarakat adat dan pengelolaan serta pemanfaatan Tanah Adat diwilayah Kedamangan kecamatan Timpah yaitu terdapat dalam Pergub. Kalimantan Tengah Nomor 13 Tahun 2009 tentang Tanah Adat dan Hak-Hak Adat di atas Tanah di Provinsi Kalimantan Tengah. Yang tertuang dalam Pasal 1 ayat (15), Pasal 2 ayat (1, 2, dan 3), Pasal 8 ayat (1), Pasal 9, 10, dan Pasal 11.

\section{DAFTAR PUSTAKA}

Bakri, Muhamad, 2007. Hak Menguasai Tanah oleh Negara. Jakarta ; Bina Aksara.

Bushar, Muhammad, 1981. Pokok-Pokok Hukum Adat. Jakarta ;PT. Pradnya Paramita.

Daron, Punding W, 2003.Tentang Kewajiban Masyarakat dalam memelihara, melestarikan, mengembangkan, dan ingin memiliki Hak Adat berupa : Tanah, Hutan untuk dijadikan Hutan Lindung, tempat berladand/berkebun, persawahan serta tempat berusaha dan berlindung dalam mempertahankan hidup menurut adat dayak ngaju, di wilayah kedemangan Timpah, Kec. Timpah, Kab. Kapuas, Provinsi Kalimantan Tengah.

Harson, Boedi, 2007. Hukum Agraria Indonesia. Jakarta ;Djambatan.

Tim Penyusun, 2008. Peraturan Daerah Provinsi Kalimantan Tengah Nomor: 16 tahun. Tentang Kelembagaan Adat Dayak Di Kalimantan Tengah. 
Peraturan Gubernur Kalimantan Tengah Nomor: 13 tahun 2009. Tentang

Tanah Adat dan Hak-Hak Adat di Atas Tanah di Provinsi Kalimantan Tengah.

Undang-Undang Dasar 1945. Karya Utama Surabaya.

Undang-Undang Nomor: 5 Tahun 1960, tentang Peraturan Dasar Pokok-Pokok Agraria. 